\title{
Rapid and selective mobilization of specific stem cell types after consumption of a polyphenol-rich extract from sea buckthorn berries (Hippophae) in healthy human subjects
}

This article was published in the following Dove Press journal:

Clinical Interventions in Aging

\section{Christian Drapeau' \\ Kathleen F Benson ${ }^{2}$ \\ Gitte $S$ Jensen ${ }^{2}$ \\ 'Biomx Stemceuticals, Austin, TX \\ 78765, USA; ${ }^{2}$ NIS Labs, Klamath Falls, OR 97601, USA}

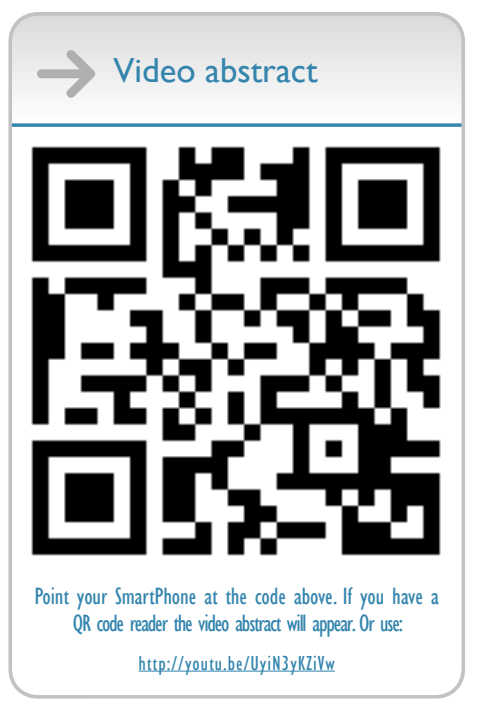

Correspondence: Christian Drapeau Biomx Stemceuticals, PO Box 49699, Austin, TX 78765, USA

Email christian@biomxstemceuticals.com
Purpose: The aim of this study was to evaluate the effects of a proanthocyanidin-rich extract of sea buckthorn berry (SBB-PE) on the numbers of various types of adult stem cells in the blood circulation of healthy human subjects.

Study design and methods: A randomized, double-blind, placebo-controlled, cross-over trial was conducted in 12 healthy subjects. Blood samples were taken immediately before and at 1 and 2 hours after consuming either placebo or $500 \mathrm{mg}$ SBB-PE. Whole blood was used for immunophenotyping and flow cytometry to quantify the numbers of CD45dim CD34+ CD309+ and CD45dim CD34+ CD309- stem cells, CD45-CD31+CD309+ endothelial stem cells, and CD45-CD90+ mesenchymal stem cells.

Results: Consumption of SBB-PE was associated with a rapid and highly selective mobilization of CD45 dim CD34+ CD309- progenitor stem cells, CD45- CD31+ CD309+ endothelial stem cells, and CD45- CD90+ lymphocytoid mesenchymal stem cells. In contrast, only minor effects were seen for CD45dim CD34+ CD309+ pluripotential stem cells.

Conclusion: Consumption of SBB-PE resulted in selective mobilization of stem cell types involved in regenerative and reparative functions. These data may contribute to the understanding of the traditional uses of SBB for preventive health, regenerative health, and postponing the aging process.

Keywords: CD31, CD34, CD90, CD309, endothelial stem cells, mesenchymal stem cells

\section{Introduction}

Over the past decade, there is a growing interest among the aging adult population to devote efforts into health maintenance instead of disease management. ${ }^{1,2}$ This trend happens coincidentally with an overall aging of the world population due to decreasing fertility rates combined with increased life expectancy, ${ }^{3}$ which is associated with a growing disease burden. ${ }^{4}$ Overall, health maintenance or disease prevention involves much lesser costs, and it is associated with much greater quality of life. ${ }^{5,6}$ This includes the consumption of high-quality nutrients, probiotics, vitamin and mineral supplements, botanical stem cell enhancers, and nutrient-dense fruits and berries such as amla, acai, maqui berry, and goji berry.

Another plant with a long-standing traditional use in health maintenance, as well as disease prevention and treatment, is sea buckthorn (SB). SB is a thorny nitrogen-fixing deciduous shrub native to the cold and arid regions of North Western Europe and Central Asia. ${ }^{7}$ Although its cultivation has spread as far as $\mathrm{Canada}^{8}$ and South America, ${ }^{9}$ 
SB grows naturally at high altitudes $(2,500-4,000 \mathrm{~m})$ on the Tibetan Plateau, Ladakh, Uttarakhand, Himachal Pradesh, Jammu and Kashmir, Sikkim, and Arunachal Pradesh regions. ${ }^{10} \mathrm{SB}$ is highly resistant to extreme temperature and conditions of drought and abundant rain, as well as high levels of soil salinity and acidity. ${ }^{11,12}$ This is in part due to the fact that the roots bear bulbs that contain nitrogen-fixing bacteria, providing the development of an extensive root system in a wide spectrum of climatic conditions. ${ }^{13}$ For this reason, SB has been strategically propagated and cultivated in regions such as Central China to prevent soil erosion, providing an opportunity to harvest wild grown berries.

The small berries (sea buckthorn berry [SBB]), of 5-8 $\mathrm{mm}$ in diameter, are spread over the length of thorny branches covered with leaves. The berry consists of a dark brown seed $(23 \% \mathrm{w} / \mathrm{w}), 2.8-4.2 \mathrm{~mm}$ long, wrapped in a juicy flesh $(63 \% \mathrm{w} / \mathrm{w})$ covered with a clear orange skin $(7.8 \% \mathrm{w} / \mathrm{w}){ }^{14,15}$ The taste of SBB is unique and cannot be compared with any other berry or fruit, owing to its aroma due to volatile compounds such as ethyl dodecanoate, ethyl octanoate, decanol, ethyl decanoate, and ethyl dodecanoate. ${ }^{16,17}$

Fruits, seeds, and leaves have all been shown to contain a wide variety of compounds known for promoting health maintenance. ${ }^{13,18}$ However, the actual chemical composition of the berries and leaves greatly depends on the climatic conditions, ripeness, and harvesting and processing methods. ${ }^{19}$ For example, berries grown at high altitude in harsh conditions of seasonal drought and extreme temperatures were documented to contain up to 10 times the amount of vitamin $\mathrm{C}$ found in berries grown at lower altitudes. ${ }^{9}$ Interestingly, SBB does not contain ascorbinase, which hydrolyses ascorbate, thus preserving vitamin $\mathrm{C}$ in the juice or dried berry. ${ }^{13}$ Overall, SBB is a good source of minerals, especially calcium, phosphorous, iron, and potassium, as well as vitamins C, B1, B2, E, A, and K..$^{13,14,20-22} \mathrm{SBB}$ is also a good source of carotenoids, mainly $\beta$-carotene, lycopene, lutein, and zeaxantin; ${ }^{14}$ phytosterols, mainly ergosterol, stigmasterol, lanosterol, and amyrins; ${ }^{23}$ polyphenols, notably proanthocyanidins $;{ }^{9}$ and flavonoids, mainly quercetin, kaempferol, myricetin, and isorhamnetin. ${ }^{22}$ Other bioactive compounds also identified in SBB include hippophae cerebroside, oleanolic acid, ursolic acid, 19-alpha-hydroxyursolic acid, dulcioic acid, 5-hydroxymethyl-2-furancarboxaldehyde, cirsiumaldehyde, octacosanoic acid, palmitic acid, and 1-O-hexadecanolenin. ${ }^{24}$

This blend of compounds provides SBB with obvious antioxidant properties that have been widely documented and even reported to be higher than 2,6-di-tert-butyl-p-hydroxytoluene (BHT) and tert-butyl-hydroxyanisole (BHA), commonly used in food preservation. ${ }^{25,26}$ SBB extracts have been reported to prevent plasma lipid peroxidation, cytotoxicity, and even DNA damage. ${ }^{25,27}$

Interestingly, the scientific name for SB, Hippophae, refers not to its physical characteristics but to its effect on health. It is derived from the Greek words "hippo" (horse) and "phae" (light) and essentially means "shining horse". It is reported that after abandoning horses wounded in battle in a field of SB shrubs, Alexander the Great discovered on his return from battle a herd of healthy horses with shiny coats, a sign of health in a horse. SB was then brought to Greece where it has been used for centuries as feed for horses. ${ }^{18}$ A similar story has been reported with Genghis Khan who, the legend says, ordered his soldiers to harvest berries and leaves to heal faster from battle wounds.

The health benefits of SBB have been recognized for more than a thousand years in Tibetan, Mongolian, and Chinese medicine. In China, its medicinal properties were recorded in the Sibu Yidian from the Tang Dynasty and Jing Zhu Ben Cao from the Qing Dynasty. In Tibet, references to SBB were found in medicinal texts such as "rGyud-bzi" (The Four Books of Pharmacopeia) at the times of the Tang Dynasty (618-907AD). ${ }^{28,29}$ In Tibetan and Mongolian traditional medicine, SBB has been used to improve blood circulation and to treat a long list of ailments including lung conditions such as asthma, diabetes, stomach ulcers, cancer, wounds, metabolic disorders, and inflammation. ${ }^{9,18,30}$

While some of the benefits on cardiovascular health and diabetes have been corroborated by Western science, few mechanisms of action aside from SBB's antioxidant properties have been proposed to explain its wide range of health benefits. Table 1 lists the documented benefits of SB. ${ }^{31-60}$ Other plants associated with wide ranges of health benefits have been previously reported to act by triggering the release of stem cells from the bone marrow. ${ }^{61-63}$ By mobilizing more stem cells to enter the blood circulation, more stem cells are available to participate in the process of tissue repair in the body. Given the wide range of benefits associated with the use of SBB, in this study, we investigated the effect of the consumption of a proanthocyanidin-rich extract of SBB (SBB-PE) on stem cell mobilization.

\section{Materials and methods Study design}

The clinical study followed a randomized, double-blinded, placebo-controlled crossover design. Twelve people were screened and enrolled after providing written informed consent, and this study was conducted in accordance with the Declaration of Helsinki and approved by the Sky Lakes 
Table I Biological activities associated with SBBs

\begin{tabular}{|c|c|c|c|}
\hline Applications & Health benefits & Mechanism of action & Reference \\
\hline \multirow[t]{7}{*}{ Cardiovascular } & $\begin{array}{l}\text { Inhibitory effect of SBB flavonoids on NF-kappa B activation in } \\
\text { cardiomyocytes }\end{array}$ & Suggested antioxidant properties & 31,32 \\
\hline & SB oil affects lipid metabolism in atherosclerosis & Mechanism unknown & 33,34 \\
\hline & $\begin{array}{l}\text { SBB antioxidants reduced risk factors for coronary heart } \\
\text { disease in humans }\end{array}$ & Suggested antioxidant properties & 35 \\
\hline & SBB reduced the oxidative stress in human plasma & Suggested antioxidant properties & 25 \\
\hline & $\begin{array}{l}\text { SBB reduced blood pressure, plasma lipids, and increased } \\
\text { ventricular capillary density }\end{array}$ & Mechanism unknown & 36 \\
\hline & SBB flavones prevented in vivo thrombogenesis & Inhibition of platelet aggregation & 37 \\
\hline & $\begin{array}{l}\text { SB seed flavones suppressed hypertension, hyperinsulinemia, } \\
\text { and dyslipidemia }\end{array}$ & $\begin{array}{l}\text { In part by improving insulin sensitivity and } \\
\text { blocking angiotensin II }\end{array}$ & 38 \\
\hline \multirow[t]{3}{*}{ Gastric ulcer } & SBB extract reduced ulcer number and size & May be by increasing glutathione level & 39,40 \\
\hline & SB oil reduced ulcer & Mechanism unknown & 41 \\
\hline & SB oil reduced ulcer in dogs & Mechanism unknown & 42 \\
\hline \multirow[t]{4}{*}{$\begin{array}{l}\text { Antitumor, } \\
\text { anticarcinogenic }\end{array}$} & $\begin{array}{l}\text { SB oil showed anticancer properties } \\
\text { Isorhamnetin, a SBB flavone, had antiproliferative activity } \\
\text { against lung cancer }\end{array}$ & $\begin{array}{l}\text { Suggested antioxidant properties } \\
\text { Upregulation of apoptotic genes }\end{array}$ & $43-45$ \\
\hline & Isorhamnetin suppressed colon cancer cell growth & Inhibition of PI3K-Akt-mTOR pathway & 46 \\
\hline & $\begin{array}{l}\text { SBB extract showed antitumor activity in in vivo two-stage } \\
\text { carcinogenesis test in mice }\end{array}$ & Mechanism unknown & 47 \\
\hline & SBB polysaccharide inhibited Lewis lung carcinoma & Through immunostimulation & 48 \\
\hline \multirow[t]{2}{*}{ Obesity } & SB leaves reduced visceral fat in obese mice & Suggested antioxidant properties & 49,50 \\
\hline & SB leaves reduced adipogenic and lipogenic gene expression & $\begin{array}{l}\text { Upregulation of PPAR; reduction in } \\
\text { acetyl-CoA carboxylase }\end{array}$ & 51 \\
\hline \multirow[t]{6}{*}{ Diabetes } & SB seed extract had hypoglycemic effect in STZ-treated mice & Mechanism unknown & 52 \\
\hline & $\begin{array}{l}\text { SB pulp reduced glycemia, restored pancreatic beta cells in } \\
\text { STZ-treated mice }\end{array}$ & Mechanism unknown & 53 \\
\hline & SB leaf extract inhibited alpha-glucosidase & Inhibition of alpha-glucosidase & 54 \\
\hline & $\begin{array}{l}\text { SBB lowered fasting and postprandial glycemia by increasing } \\
\text { insulin secretion }\end{array}$ & Mechanism unknown & 55 \\
\hline & $\begin{array}{l}\text { SBB extract suppressed postprandial peak insulin response and } \\
\text { stabilized postprandial hyperglycemia }\end{array}$ & Mechanism unknown & 56 \\
\hline & SB fruit oil alleviated type 2 diabetes & Through PI3K/Akt signaling pathway & 57 \\
\hline \multirow[t]{3}{*}{ Wound healing } & SB flavones promoted wound healing & Mechanism unknown & 58 \\
\hline & SB leaf extract accelerated would healing & Upregulation of VEGF and angiogenesis & 59 \\
\hline & SB seed oil help heal burn wounds & $\begin{array}{l}\text { Enhance microcirculation and tissue } \\
\text { regeneration }\end{array}$ & 60 \\
\hline
\end{tabular}

Abbreviations: SB, sea buckthorn; SBB, sea buckthorn berry; STZ, streptozotocin.

Medical Center Institutional Review Board (FWA 2603). The trial is registered at ClinicalTrials.gov (ClinicalTrials.gov Identifier: NCT03388073). The study population included eight females and four males with an average age of $49.3 \pm 21$ years and a body mass index (BMI) between 20.0 and $34.6 \mathrm{~kg} / \mathrm{m}^{2}$ (Table 2), with no known chronic illness, frequent recreational drug use, impaired digestive function (including previous major gastrointestinal surgery), or known allergies to berry products. The study participants were scheduled for two clinic visits at least 1 week apart. The visits were always scheduled at the same time of the day for each person, the same day of the week, and always during the morning hours of 7-11 am to minimize the effect of circadian fluctuations. Since there is a well-documented interference from exercise ${ }^{64}$ and stress ${ }^{65-68}$ with the release vs homing of lymphocytes, the study environment was managed to minimize the physical and mental stress before and during testing. On arrival to each clinic visit, study participants completed a questionnaire to help monitor exceptional circumstances that might be affecting the stress level of that person on that day. Predetermined criteria for re-scheduling a visit included sleep deprivation and acute anxiety. After completing the questionnaire, 
Table 2 Demographics of the study population

\begin{tabular}{|l|l|l|l|}
\hline Study participants & Gender & Age (years) & BMI $\left.\mathbf{( k g} / \mathbf{m}^{2}\right)$ \\
\hline P0I & F & 56 & 32.5 \\
\hline P02 & F & 62 & 23.6 \\
\hline P03 & F & 62 & 30.8 \\
\hline P04 & F & 32 & 23.5 \\
\hline P05 & M & 28 & 22.1 \\
\hline P06 & M & 59 & 29.8 \\
\hline P07 & M & 49 & 31.7 \\
\hline P08 & F & $6 I$ & 24.5 \\
\hline P09 & M & 70 & 21.0 \\
\hline PI0 & F & 56 & 22.0 \\
\hline PII & F & 55 & 34.6 \\
\hline PI2 & F & 51 & 23.3 \\
\hline Average & & 53.4 & 26.6 \\
\hline SD & & 12.3 & 4.9 \\
\hline Range & & $28-70$ & $21.0-34.6$ \\
\hline
\end{tabular}

Abbreviations: BMI, body mass index; F, female; $M$, male.

volunteers were instructed to remain calm and inactive for 3 hours, comfortably seated in a chair. After the first hour, the baseline blood sample was drawn. Immediately after the baseline sample was drawn, an encapsulated test product was provided with water and consumed in the presence of the clinic staff. Blood samples were drawn at 1 and 2 hours after ingestion of the test product or placebo. At each blood draw, $6 \mathrm{~mL}$ of blood was drawn into sodium heparin vacutainer tubes for subsequent immunostaining. The heparin vials were placed on a rocker until staining, which was initiated within the hour of each blood draw.

\section{Consumables}

A proanthocyanidin-rich water extract of whole SBBs (Puredia, Irvine, CA, USA) was encapsulated at NIS Labs with $500 \mathrm{mg} /$ dose. Placebo capsules were prepared using rice flour. Study participants and clinic staff were blinded to the consumables. Randomization was performed following the Latin Square design, such that half the study participants received the active test product at the first visit and placebo at the second visit, and the other half of the study participants received products in the reverse sequence.

\section{Stem cell evaluation by flow cytometry}

For each blood draw, triplicate samples of $100 \mu \mathrm{L}$ of heparinized whole blood was stained using the following four-color immunostaining panel: CD31-FITC, CD34-PerCP, CD45PO, and CD133-PE. For eight of the study participants, a fifth color was added: CD90-v421. Staining was performed as recommended by Thermo Fisher Scientific (Waltham, MA, USA) for whole blood staining followed by a "no-wash" procedure involving Cal-Lyse ${ }^{\circledR}$ fixation of white blood cells and lysing of red blood cells. In brief, samples were stained in the dark at room temperature for 15 minutes followed by the addition of $100 \mu \mathrm{L}$ of Cal-Lyse ${ }^{\circledR}$ Lysing solution and fixation for 10 minutes at room temperature. Red blood cells were then lysed by the addition of $1 \mathrm{~mL}$ of deionized water and further 10 minutes incubation in the dark at room temperature. Samples were stored at $4^{\circ} \mathrm{C}$ in the dark and acquired by flow cytometry within 24 hours using an acoustic-focusing Attune $^{\mathrm{TM}}$ flow cytometer (Thermo Fisher Scientific). Files of 300,000-600,000 events were collected for each triplicate sample. Data on stem cell numbers were analyzed by the Attune software (Thermo Fisher Scientific) that provides results as cell per microliter of sample and compensated for the dilution factor that was part of the immunostaining protocol, so the results were converted to stem cell numbers per microliter of whole blood.

\section{Statistical analyses}

Average and SD for each data set were calculated using Excel (Microsoft Corporation, Redmond, WA, USA). The statistical significance of post-consumption changes from baseline to later assessments was evaluated by betweentreatment analysis using within-subject analysis and the two-tailed paired $t$-test. Statistical significance was indicated by $P<0.05$, and a high level of significance was indicated by $P<0.01$.

\section{Results}

\section{Study population and compliance}

The demographic characteristics for the study participants are shown in Table 2. All 12 study participants completed the study participation with full compliance, including adhering to similar routines and food for 12 hours prior to arrival on both clinic days, remaining calm and unstressed during the 3-hour clinic visits, consuming test products with water as instructed, and allowing the three blood draws at each visit.

\section{Post-consumption changes in circulating stem cells}

Each blood sample was used to perform immunostaining and flow cytometry to evaluate the post-consumption changes to the numbers of three different subtypes of circulating stem cells. For eight of the study participants, post-consumption changes to a subset of mesenchymal stem cells (MSCs), 
identified in the absence of CD45 and the expression of CD90 on cells within the lymphocyte gate were also evaluated.

Given interindividual variations in the time course of the mobilizing response following the consumption of SBB-PE, some individuals showed a greater response at 1 hour, whereas others showed a greater response at 2 hours. Therefore, simply averaging the responses at the respective time points may underestimate the actual response and provide greater SDs. For this reason, an additional analysis was performed using the data from the time point that showed the greatest response.

\section{Changes in the number of stem cells expressing CD34}

CD34 is a transmembrane protein that is expressed almost exclusively on certain types of stem cells. Lymphocytoid CD34+ stem cells are also showing a low level of expression of the protein tyrosine phosphatase receptor type $\mathrm{C}$ enzyme, CD45 (CD45dim). This is in contrast to mature hematopoietic cells that show a high level of cell surface CD45 expression ${ }^{69,70}$ and to other types of stem cells that are completely negative for CD45 (CD45-). ${ }^{71}$ The changes in CD45dim CD34+ stem cell numbers were analyzed to see whether the effects of consuming SBB-PE altered the levels of CD34+ stem cells in the circulation.

\section{A}
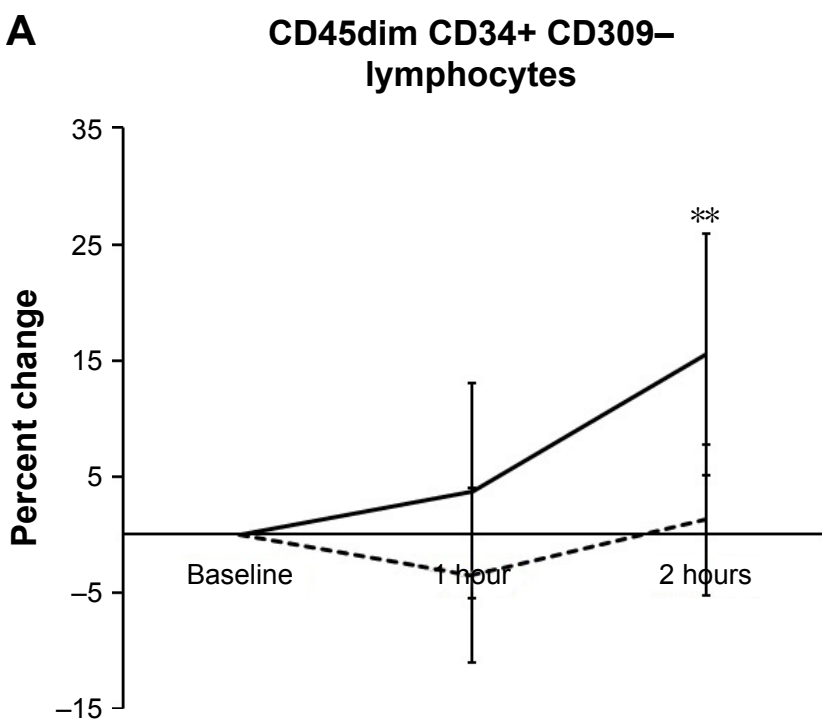

The CD45dim CD34+ stem cell population is further divided into two subtypes, based on whether the cells express the CD309 antigen, a transmembrane tyrosine kinase also known as vascular endothelial growth factor receptor-2 (VEGFR-2) and kinase insert domain-containing receptor (KDR; CD309). The presence of CD309 on stem cells has been associated with a more pluripotent (ie, undifferentiated) phenotype. ${ }^{72}$ Furthermore, the expression of CD309 on CD34+ cells in the circulation has been implicated with vascular maintenance and repair. ${ }^{73}$ The absence of CD309 on $\mathrm{CD} 34+$ stem cells has been associated with a progenitor phenotype. ${ }^{74}$ Consumption of SBB-PE triggered a selective mobilization of CD45dim CD34+CD309- cells, in contrast to no changes to CD45dim CD34+ CD309+ pluripotential stem cells (Figure 1). When considering the greatest response at either 1 or 2 hours, the number of circulating CD45dim CD34+ CD309- cells and CD45dim CD34+ CD309+ cells increased by $24.2 \% \pm 5.3 \%(P<0.001)$ and $19.5 \% \pm 7.0 \%$ $(P<0.016)$, respectively (Figure 4$)$.

\section{Changes in endothelial stem cells}

The immunophenotyping also included the assessment of circulating endothelial stem cells with the phenotype of CD45-CD31+CD309+. ${ }^{75}$ Endothelial stem cells have been shown to be rapidly mobilized following acute myocardial

\section{B CD45dim CD34+ CD309+ lymphocytes}

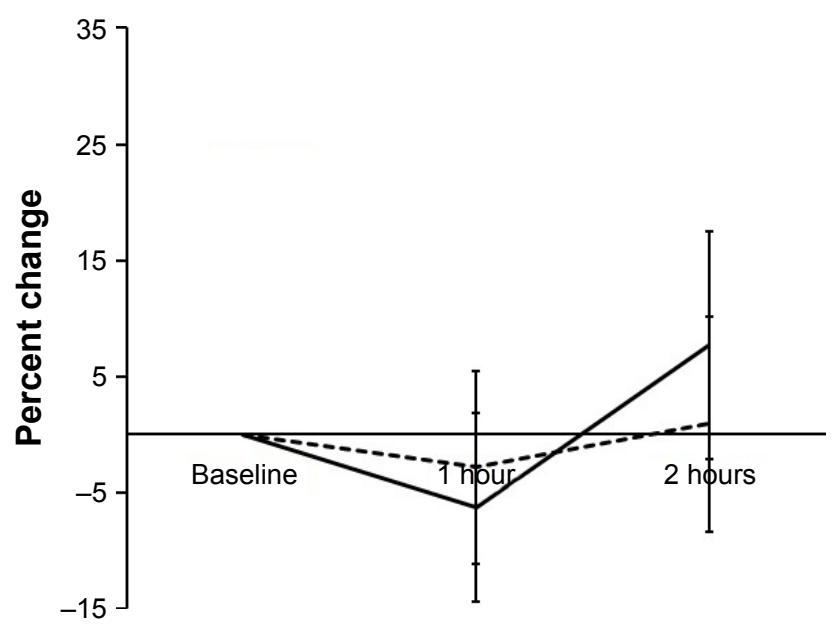

Figure I Changes in CD45dim CD34+ stem cells within 2 hours of consuming SBB-PE vs placebo.

Notes: The results are shown as the average \pm SEM of the individual percent changes from baseline after consuming either SBB-PE (solid line) or placebo (dashed line). (A) For the CD45dim CD34+ CD309- lymphocytes, the difference between the treatments did not reach statistical significance $(P<0.17)$; however, the increase in CD45dim CD34+ CD309- stem cells at 2 hours after consuming SBB-PE was highly significant when comparing to baseline (**P $<0.007)$. (B) In contrast, there were no significant changes in the CD45dim CD34+ CD309+ stem cells after consuming either SBB-PE or placebo.

Abbreviations: SBB-PE, proanthocyanidin-rich extract of sea buckthorn berry; SEM, standard error of the mean. 
infarction $^{76,77}$ and are being actively researched for use in regenerative medicine. Consumption of SBB-PE triggered mobilization of CD45- CD31+ CD309+ endothelial stem cells, in contrast to placebo where a mild reduction was seen, likely part of the normal circadian rhythm for this cell type. The difference in the numbers of circulating CD45- CD31+ CD309+ endothelial stem cells after consumption of SBB-PE vs placebo was statistically significant at 1 hour $(P<0.04)$ and after 2 hours ( $P<0.05$; Figure 2$)$. When considering the greatest response at either 60 or 120 minutes, the number of circulating CD45- CD31+ CD309+ cells increased by $33.4 \% \pm 10.2 \%(P<0.007$; Figure 4$)$.

\section{Changes in MSCs}

For eight of the twelve study participants, the changes in numbers of lymphocytoid stem cells that expressed the mesenchymal stem cell marker CD90 was evaluated. The lymphocytoid stem cells that expressed the mesenchymal stem cell marker CD90 were negative for CD45. Postconsumption changes showed an increase in CD45- CD90+ lymphocytoid stem cells at 1 hour and 2 hours after consuming SBB, in contrast to only minor changes after consuming placebo. The increase at 2 hours, compared to baseline, reached a borderline statistical trend $(P<0.11)$ (Figure 3$)$. When considering the greatest response at either 60 or 120 minutes, the number of circulating CD45- CD90+ lymphocytoid stem cells increased by $20.8 \pm 5.7 \%(P<0.016)$ (Figure 4).

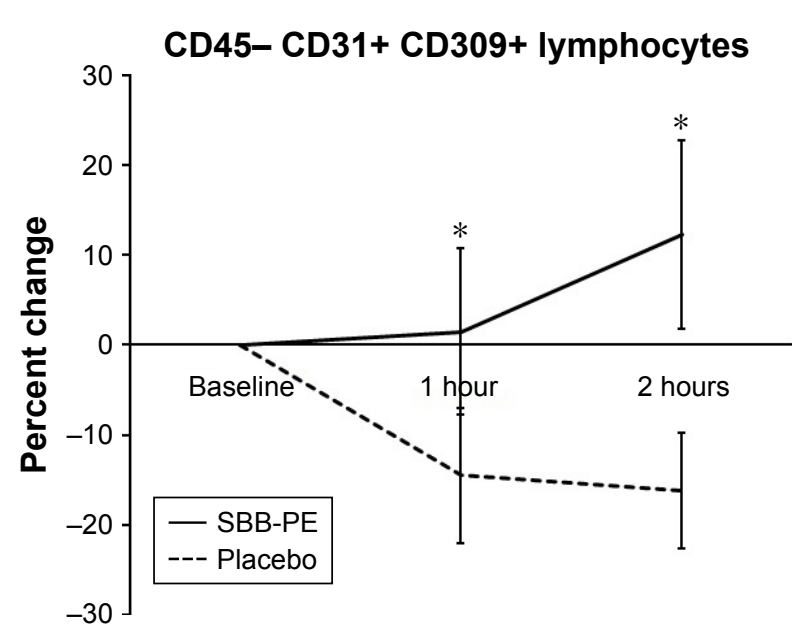

Figure 2 Changes in CD45- CD3 I+CD309+ endothelial stem cells within 2 hours of consuming SBB-PE vs placebo.

Notes: The results are shown as the average \pm SEM of the individual percent changes from baseline after consuming either SBB-PE (solid line) or placebo (dashed line). There was no significant difference between the treatments; however, the increase in CD45-CD31+CD309+ endothelial stem cells at I and 2 hours after consuming SBB-PE was statistically significant when comparing to baseline $\left({ }^{*} P<0.05\right)$.

Abbreviations: SBB-PE, proanthocyanidin-rich extract of sea buckthorn berry; SEM, standard error of the mean.

\section{Discussion}

The migration of stem cells, seeking sites in need of repair, is crucial for the processes involved in ongoing normal maintenance and rejuvenation of healthy tissue, as well as for specific repair and healing of injured tissue. Therefore, the documentation of stem cell mobilization after consuming a botanical SBB-PE suggests a mechanism for the traditional uses of SBB in folk medicine. The basic definition of a stem cell is an undifferentiated cell that can self-replicate and also can develop into any one of various kinds of cells (such as blood cells, skin cells, nerve cells, etc.). There are multiple types of stem cells, each having distinct phenotypes. Pluripotential stem cells have the capacity to differentiate into hematopoietic and non-hematopoietic lineages. MSCs (also known as multipotent mesenchymal stromal cells) are non-hematopoietic and possess the capacity for self-renewal and multi-lineage differentiation, including osteoblasts, chondrocytes, neurons, muscle cells, adipocytes, and insulinexpressing cells in pancreatic islets. MSCs have also been demonstrated to have unique immunomodulatory properties including their ability to reduce immune cell infiltration and to modulate inflammation.

The response to consuming SBB-PE was selective and involved specific types of stem cells, whereas the numbers of other types of stem cells in the blood circulation did not change. The CD45dim CD34+ CD309- cells, CD45dim CD34+ CD309+ cells, and the CD45- CD31+ CD309+ endothelial stem cells showed significant mobilization above placebo within 2 hours. Regarding their regenerative properties, the number of circulating stem cells has been documented to be a critical parameter. When the number of circulating endothelial progenitor cells was quantified in the blood of 509 individuals at risk for cardiovascular disease and the incidence of cardiovascular events in these individuals was monitored for 1 year, a significantly greater number of events took place in the individuals having fewer circulating stem cells. In this study, the number of circulating stem cells was documented as one of the best predictor of cardiovascular health. ${ }^{78}$ Likewise, following acute myocardial infarction, individuals with a higher baseline number of circulating stem cells showed a greater ejection fraction 6 months later. ${ }^{79}$ A link between a lower number of circulating stem cells and the development of degenerative diseases has been established with diabetes, ${ }^{80}$ cardiovascular diseases, ${ }^{81}$ atherosclerosis, ${ }^{82,83}$ Alzheimer's disease, ${ }^{84,85}$ rheumatoid arthritis, ${ }^{86,87}$ pulmonary diseases, ${ }^{88,89}$ erectile dysfunction, ${ }^{90,91}$ and muscular dystrophy. ${ }^{92}$ 


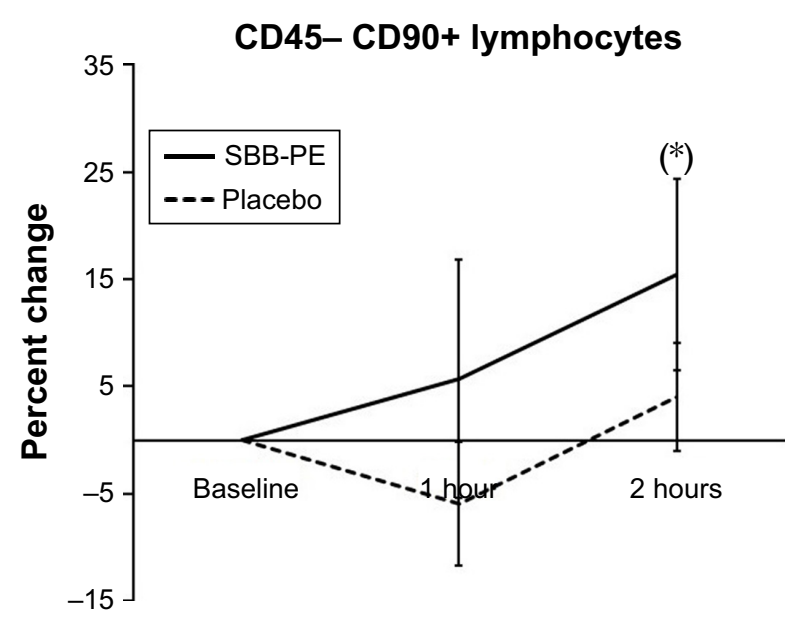

Figure 3 Changes in circulating CD90+ mesenchymal stem cell subpopulations. Notes: The results are shown as the average \pm SEM of the individual percent changes from baseline after consuming either SBB-PE (solid line) or placebo (dashed line). For the CD45- CD90+ lymphocytes, the difference between the treatments did not reach statistical significance; however, the increase in CD45dim CD90+ mesenchymal stem cells at 2 hours after consuming SBB-PE reached a statistical trend $(* P<0.1)$.

Abbreviations: SBB-PE, proanthocyanidin-rich extract of sea buckthorn berry; SEM, standard error of the mean.

Furthermore, increasing the number of circulating stem cells has been documented to enhance tissue repair or to improve the course of disease formation in cases of acute myocardial infarction, ${ }^{93,94}$ stroke, ${ }^{95}$ bone fracture, ${ }^{96}$ muscle injury, ${ }^{97}$ spinal cord injury, ${ }^{98}$ diabetic wound healing, ${ }^{99}$ and inner ear damage, ${ }^{100}$ to name a few. Stem cell mobilization using an extract of the cyanophyta species Aphanizomenon flos-aquae was documented to improve cases of severe cardiomyopathy, stroke, diabetes, rheumatoid arthritis, kidney failure, and Parkinson's disease. ${ }^{62}$ An extract of Rehmannia glutinosa was also shown to trigger stem cell mobilization via a CXCR4-dependent mechanism and to improve the outcome of myocardial infarction. ${ }^{101}$ Altogether, these data suggest that SBB-PE could be a novel natural stem cell mobilizer with the potential of improving the course of several degenerative diseases.

We have shown here that consuming SBB-PE leads to selective increase in circulating CD45- CD90+ lymphocytes. Stem cells were also shown to play an important paracrine role, which includes cross-talk with other cell types and profound regulating effects such as reducing inflammation, ${ }^{102}$ which can play an important role in wound healing. MSCs expressing CD90 are capable of suppressing inflammatory conditions by various mechanisms. This has been well documented in various types of tissue models, including dental pulp stem cells that have shown immunomodulatory effects where specific inflammatory macrophage activity and cytokine profile are suppressed. ${ }^{103}$ MSCs also support a shift in macrophage polarization from the highly inflammatory "M1" toward the anti-inflammatory "M2" type, which is known to facilitate wound healing and is also associated with changes in metabolic health and glucose metabolism. ${ }^{104}$ Thus, reparative effects of stem cells in, for example, diabetes may involve repair through regeneration of pancreatic beta-cells, but may also involve an immunological shift in macrophage polarization, positively supporting an improved metabolic health.

Resolution of inflammation is essential to successful healing of wounds and damaged tissue, and chronic inflammation can lead to poor healing outcomes. ${ }^{105}$ The plasticity within the stem cell hierarchy is important and even though the hierarchy places pluripotential stem cells at the top, with

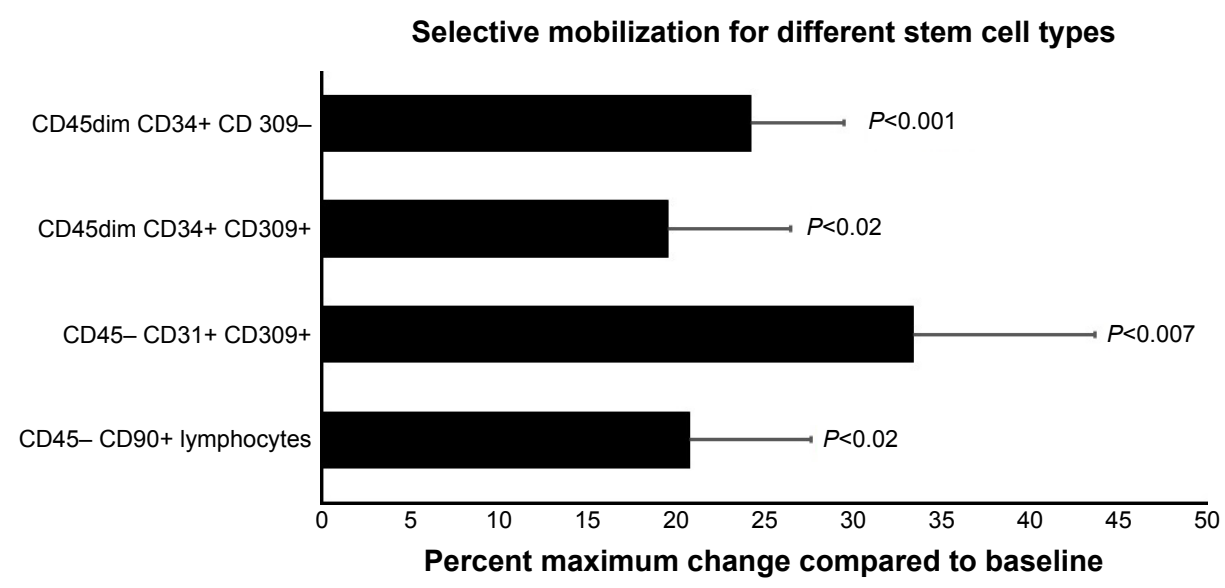

Figure 4 The maximum change (I or 2 hours) after consumption of SBB-PE.

Notes: The maximum changes in stem cell numbers, whether seen at I or 2 hours after consumption of SBB-PE, were adjusted for the matching placebo response for each person, and the results are represented as average \pm SEM. The analysis of the acute effects on stem cell mobilization reduced the individual variations and showed significant changes above placebo.

Abbreviations: SBB-PE, proanthocyanidin-rich extract of sea buckthorn berry; SEM, standard error of the mean. 
endothelial, mesenchymal, and hematopoietic stem cells at a further differentiated state, the possibility exists to revert back to the pluripotent state. ${ }^{106}$ The ability of MSCs to modulate the inflammatory response in wounds includes both a reduction in infiltration of inflammatory cells and a reduction in pro-inflammatory cytokines such as interleukin (IL)-1 and tumor necrosis factor (TNF)-alpha. This ability also supports their favorable effect on the healing response, and there is an increasing interest in non-invasive use of plant extract for regenerative medicine. ${ }^{107}$ The clinical importance of stem cell mobilization in reparative functions is well documented for improvement in diabetic conditions ${ }^{108}$ and cardiovascular repair after infarct, ${ }^{109}$ and therefore, natural stem cell mobilizers such as SBB-PE could be effective tools to improve overall health and to accelerate the healing process by supporting the actual process of tissue repair and reducing inflammation.

\section{Conclusion}

By documenting the ability of SBB-PE to support stem cell mobilization and to increase the number of circulating stem cells, we have uncovered a new mechanism of action behind many of the health benefits that have been historically associated with SBB, as a part of its use in Tibetan, Mongolian, and Chinese traditional medicine. Once mobilized, bone marrow stem cells can participate in the process of tissue repair and modulate local inflammation, supporting the use of SBB-PE in overall health maintenance.

\section{Data sharing statement}

The authors do not plan to share individual de-identified participant data beyond the data presentation in this manuscript.

\section{Acknowledgments}

This study was conducted at NIS Labs, an independent contract research organization that specializes in natural products research. The study was co-sponsored by Biomx Stemceuticals LLC and NIS Labs R\&D, Inc.

\section{Author contributions}

CD and GSJ planned the testing of sea buckthorn for stem cell effects. CD researched the historical use and current scientific knowledge about sea buckthorn. GSJ designed and oversaw the clinical study. KFB conducted the stem cell staining and flow cytometry. KFB and GSJ analyzed the data and interpreted the results. CD and GSJ co-wrote the manuscript. All authors contributed to data analysis, drafting or revising the article, gave final approval of the version to be published, and agree to be accountable for all aspects of the work.

\section{Disclosure}

$\mathrm{CD}$ is the co-founder and executive director of Biomx StemCeuticals LLC, and GSJ is the research director for NIS Labs. The authors report no other conflicts of interest in this work.

\section{References}

1. Kantor ED, Rehm CD, Du M, White E, Giovannucci EL. Trends in dietary supplement use among US adults from 1999-2012. JAMA. 2016; 316(14):1464-1474.

2. Denham BE. Psychosocial correlates of dietary supplement use: results from the national survey of midlife development in the United States. Ecol Food Nutr. 2017;56(2):171-186.

3. World Health Organization [homepage on the Internet]. World report on ageing and health; 2015. Available from: http://apps.who.int/iris/ bitstream/handle/10665/186463/9789240694811_eng.pdf?sequence=1. Accessed December 21, 2018.

4. Dall TM, Gallo PD, Chakrabarti R, West T, Semilla AP, Storm MV. An aging population and growing disease burden will require a large and specialized health care workforce by 2025. Health Aff (Millwood). 2013;32(11):2013-2020.

5. Centers for Disease Control and Prevention. The Power of Prevention Chronic disease ... the public health challenge of the 21 st century. $16 \mathrm{pp}$. 2009. Available from: https://www.cdc.gov/chronicdisease/pdf/2009power-of-prevention.pdf. Accessed December 21, 2018.

6. Comlossy M. National Conference of State Legislatures. Chronic Disease Prevention and Management. 16 pp; 2013. Available from: http://www.ncsl.org/documents/health/chronicdtk13.pdf

7. Řezníček V, Plšek J. Sea buckthorn (Hippophae rhamnoides L.) - The effective source of vitamin C. In: Proceedings of the Fifth Conference on Medicinal and Aromatic Plants of South-East European Countries, (5th CMAPSEEC), Brno, Czech Republic; 2008:69 pp.

8. Yang B, Kallio HP. Fatty acid composition of lipids in sea buckthorn (Hippophaë rhamnoides L.) berries of different origins. J Agric Food Chem. 2001;49(4):1939-1947.

9. Bal LM, Meda V, Naik SN, Satya S. Sea buckthorn berries: a potential source of valuable nutrients for nutraceuticals and cosmoceuticals. Food Res Int. 2011;44(7):1718-1727.

10. Tulsawani R, Gupta R, Misra K. Efficacy of aqueous extract of Hippophae rhamnoides and its bio-active flavonoids against hypoxia-induced cell death. Indian J Pharmacol. 2013;45(3):258-263.

11. Dhyani D, Maikhuri RK, Rao KS. Basic nutritional attributes of Hippophae rhamnoides (sea buckthorn) populations from Uttarakhand Himalaya, India. Curr Sci India. 2007;92:1148-1152.

12. Khan BA, Akhtar N, Mahmood T. A comprehensive review of a magic plant Hippophae rhamnoides. Pharmacogn J. 2010;16:58-61.

13. Krejcarová J, Straková E, Suchý P, Herzig I, Karásková K. Sea buckthorn (Hippophae rhamnoides L.) as a potential source of nutraceutics and its therapeutic possibilities - a review. Acta Veterinaria Brno. 2015;84(3):257-268

14. Michel T, Destandau E, Le Floch G, Lucchesi ME, Elfakir C, Antimicrobial EC. Antimicrobial, antioxidant and phytochemical investigations of sea buckthorn (Hippophaë rhamnoides L.) leaf, stem, root and seed. Food Chem. 2012;131(3):754-760.

15. Li TSC, Beveridge, THJ, editors. Sea Buckthorn (Hippophae rhamnoides): Production and Utilization. Ottawa, ON: NRC Resarch Press; 2003:51-68.

16. Kumar R, Kumar GP, Chaurasia OP, Bala Singh S, Singh SB. Phytochemical and pharmacological profile of Seabuckthorn oil: a review. J Med Plant Res. 2011;5(5):491-499. 
17. Guliyev VB, Gul M, Yildirim A. Hippophae rhamnoides L. chromatographic methods to determine chemical composition, use in traditional medicine and pharmacological effects. J Chromatogr B Analyt Technol Biomed Life Sci. 2004;812(1-2):291-307.

18. Suryakumar G, Gupta A. Medicinal and therapeutic potential of Sea buckthorn (Hippophae rhamnoides L.). J Ethnopharmacol. 2011;138(2):268-278.

19. Leskinen HM, Suomela JP, Yang B, Kallio HP. Regioisomer compositions of vaccenic and oleic acid containing triacylglycerols in sea buckthorn (Hippophae rhamnoides) pulp oils: influence of origin and weather conditions. J Agric Food Chem. 2010;58(1):537-545.

20. Christaki E. Hippophae rhamnoides L. (Sea Buckthorn): a potential source of nutraceuticals. Food Public Health. 2012;2(3):69-72.

21. Bekker NP, Glushenkova AI. Components of certain species of the Elaeagnaceae family. Chem Nat Compd. 2001;2001(37):97-116.

22. Fatima T, Snyder CL, Schroeder WR, et al. Fatty acid composition of developing sea buckthorn (Hippophae rhamnoides L.) berry and the transcriptome of the mature seed. PLoS One. 2012;7(4):e34099.

23. Yang B, Karlsson RM, Oksman PH, Kallio HP. Phytosterols in sea buckthorn (Hippophaë rhamnoides L.) berries: identification and effects of different origins and harvesting times. J Agric Food Chem. 2001;49(11):5620-5629.

24. Zheng RX, Xu XD, Tian Z, Yang JS. Chemical constituents from the fruits of Hippophae rhamnoides. Nat Prod Res. 2009;23(15):1451-1456.

25. Olas B, Kontek B, Malinowska P, Żuchowski J, Stochmal A. Hippophae rhamnoides $\mathrm{L}$. fruits reduce the oxidative stress in human blood platelets and plasma. Oxid Med Cell Longev. 2016;2016(1):8 pp.

26. Papuc C, Diaconescu C, Nicorescu V. Antioxidant activity of sea buckthorn (Hippophae Rhamnoides) extracts compared with common food additives. Rom Biotechnol Lett. 2008;13(67):4049-4053.

27. Geetha S, Ram MS, Sharma SK, Ilavazhagan G, Banerjee PK, Sawhney RC. Cytoprotective and antioxidant activity of seabuckthorn (Hippophae rhamnoides L.) flavones against tert-butyl hydroperoxide-induced cytotoxicity in lymphocytes. J Med Food. 2009;12(1): $151-158$

28. Rousi A. The genus Hippophae L. a taxonomic study. Annals Botanica Fennici. 1971;8:177-227.

29. Bernath J, Foldesi D. Sea-buckthorn (Hippophae rhamnoides L.): a promising new medicinal and food crop. J Herbs Spices Med Plants. 1992;1:27-35.

30. Singh V. Seabuckthorn (Hippophae L.) in traditional medicines. In: Singh V, editor. Seabuckthorn (Hippophae L.): A Multipurpose Wonder Plant, vol. 2. New Delhi, India: Daya Publishing House; 2005:505-521.

31. Xiao Z, Peng W, Zhu B, Wang Z. The inhibitory effect of total flavonoids of hippophae on the activation of NF-kappa B by stretching cultured cardiac myocytes. Sichuan Da Xue Xue Bao Yi Xue Ban. 2003; 34(2):283-285. Chinese.

32. Zhang M. Treatment of ischemic heart disease with flavonoids of hippophaerhamnoides. Chin J Cardiol. 1987;15:97-99.

33. Virgolici B, Lixandru D, Casariu ED, et al. Sea buckthorn pulp oil treatment prevents atherosclerosis in obese children. ISRN Oxidative Med. 2013;2013(4):1-9.

34. Basu M, Prasad R, Jayamurthy P, Pal K, Arumughan C, Sawhney RC. Anti-atherogenic effects of seabuckthorn (Hippophaea rhamnoides) seed oil. Phytomedicine. 2007;14(11):770-777.

35. Eccleston C, Baoru Y, Tahvonen R, Kallio H, Rimbach GH, Minihane AM. Effects of an antioxidant-rich juice (sea buckthorn) on risk factors for coronary heart disease in humans. J Nutr Biochem. 2002;13(6):346-354.

36. Koyama T, Taka A, Togashi H. Effects of a herbal medicine, Hippophae rhamnoides, on cardiovascular functions and coronary microvessels in the spontaneously hypertensive stroke-prone rat. Clin Hemorheol Microcirc. 2009;41(1):17-26.

37. Cheng J, Kondo K, Suzuki Y, Ikeda Y, Meng X, Umemura K. Inhibitory effects of total flavones of Hippophae Rhamnoides L on thrombosis in mouse femoral artery and in vitro platelet aggregation. Life Sci. 2003;72(20):2263-2271.
38. Pang X, Zhao J, Zhang W, et al. Antihypertensive effect of total flavones extracted from seed residues of Hippophae rhamnoides L. in sucrose-fed rats. J Ethnopharmacol. 2008;117(2):325-331.

39. Suleyman H, Büyükokuroglu ME, Koryk M, Akcay F, Kiziltunc A, Gepdiremen A. The effects of Hippophae rhamnoides L. extract on ethanol-induced gastric lesion and gastric tissue glutathione level in rats: a comparative study with melatonin and omeprazole. Indian $J$ Pharmacol. 2001a;33:77-81.

40. Süleyman H, Demirezer LÖ, Büyükokuroglu ME, et al. Antiulcerogenic effect of Hippophae rhamnoides L. Phytother Res. 2001b;15(7): 625-627.

41. Xing J, Yang B, Dong Y, Wang B, Wang J, Kallio HP. Effects of sea buckthorn (Hippophaë rhamnoides L.) seed and pulp oils on experimental models of gastric ulcer in rats. Fitoterapia. 2002;73(7-8):644-650.

42. Dogra R, Tyagi SP, Kumar A. Efficacy of Seabuckthorn (Hippophae rhamnoides) Oil vis-a-vis other standard drugs for management of gastric ulceration and erosions in dogs. Vet Med Int. 2013;2013:176848.

43. Zeb A. Anticarcinogenic potential of lipids from Hippophae-evidence from the recent literature. Asian Pac J Cancer Prev. 2006;7(1):32-35.

44. Li Q, Ren FQ, Yang CL, et al. Anti-proliferation effects of isorhamnetin on lung cancer cells in vitro and in vivo. Asian Pac J Cancer Prev. 2015; 16(7):3035-3042

45. Guo R, Guo X, Li T, Fu X, Liu RH. Comparative assessment of phytochemical profiles, antioxidant and antiproliferative activities of Sea buckthorn (Hippophaë rhamnoides L.) berries. Food Chem. 2017;221:997-1003.

46. Li C, Yang X, Chen C, Cai S, Hu J. Isorhamnetin suppresses colon cancer cell growth through the PI3K-Akt-mTOR pathway. Mol Med Rep. 2014;9(3):935-940.

47. Yasukawa K, Kitanaka S, Kawata K, Goto K. Anti-tumor promoters phenolics and triterpenoid from Hippophae rhamnoides. Fitoterapia. 2009;80(3):164-167.

48. Wang H, Gao T, du Y, et al. Anticancer and immunostimulating activities of a novel homogalacturonan from Hippophae rhamnoides L. berry. Carbohydr Polym. 2015;131:288-296.

49. Lee HI, Kim MS, Lee KM, et al. Anti-visceral obesity and antioxidant effects of powdered sea buckthorn (Hippophae rhamnoides L.) leaf tea in diet-induced obese mice. Food Chem Toxicol. 2011;49(9):2370-2376.

50. Yang X, Wang Q, Pang ZR, Pan MR, Zhang W. Flavonoid-enriched extract from Hippophae rhamnoides seed reduces high fat diet induced obesity, hypertriglyceridemia, and hepatic triglyceride accumulation in C57BL/6 mice. Pharm Biol. 2017;55(1):1207-1214.

51. Pichiah PB, Moon HJ, Park JE, Moon YJ, Cha YS. Ethanolic extract of seabuckthorn (Hippophae rhamnoides L) prevents high-fat diet-induced obesity in mice through down-regulation of adipogenic and lipogenic gene expression. Nutr Res. 2012;32(11):856-864.

52. Zhang W, Zhao J, Wang J, et al. Hypoglycemic effect of aqueous extract of seabuckthorn (Hippophae rhamnoides L.) seed residues in streptozotocin-induced diabetic rats. Phytother Res. 2010;24(2):228-232.

53. Sharma M, Siddique MW, Shamim AM, Gyanesh S, Pillai KK. Evaluation of antidiabetic and antioxidant effects of seabuckthorn (Hippophae rhamnoides L.) in streptozotocin-nicotinamide induced diabetic rats. Open Conf Proc J. 2011;5(1):53-58.

54. Bhardwaj P, Varshneya C, Kaistha K, Tandon T. In vitro evaluation of antidiabetic and antioxidant activity of Seabuckthorn (Hippophae rhamnoides L.) leaves. J Med Plants Res. 2015;9(35):929-932.

55. Wang B, Lin L, Ni Q, Lian Su C. Hippophae rhamnoides Linn. for treatment of diabetes mellitus: a review. J Med Plants Res. 2011;5(13): 2599-2607.

56. Lehtonen HM, Järvinen R, Linderborg K, et al. Postprandial hyperglycemia and insulin response are affected by sea buckthorn (Hippophaë rhamnoides ssp. turkestanica) berry and its ethanol-soluble metabolites. Eur J Clin Nutr. 2010;64(12):1465-1471.

57. Gao S, Guo Q, Qin C, Shang R, Zhang Z. Sea Buckthorn fruit oil extract alleviates insulin resistance through the PI3K/Akt signaling pathway in Type 2 diabetes mellitus cells and rats. J Agric Food Chem. 2017;65(7):1328-1336. 
58. Gupta A, Kumar R, Pal K, Singh V, Banerjee PK, Sawhney RC. Influence of sea buckthorn (Hippophae rhamnoides L.) flavone on dermal wound healing in rats. Mol Cell Biochem. 2006;290(1-2):193-198.

59. Upadhyay NK, Kumar R, Siddiqui MS, Gupta A. Mechanism of wound-healing activity of Hippophae rhamnoides L. leaf extract in experimental burns. Evid Based Complement Alternat Med. 2011;2011: 659705.

60. Zhao Y. Clinical effects of Hippophae seed oil in the treatment of 32 burn cases. Hippophae. 1994;7:36-37. Available from: http://www. shinyhorse.com/files/SEEdOILBURNTREATMENT.pdf. Accessed December 21, 2018.

61. Jensen GS, Hart AN, Zaske LA, et al. Mobilization of human CD34+ CD133+ and CD34+ CD133(-) stem cells in vivo by consumption of an extract from Aphanizomenon flos-aquae - related to modulation of CXCR4 expression by an L-selectin ligand? Cardiovasc Revasc Med. 2007;8(3):189-202.

62. Drapeau C, Eufemio G, Mazzoni P, RToth GD, Stranberg S. The therapeutic potential of stimulating endogenous stem cell mobilization. In: Tissue Regeneration, Eds. Jamie Davies, From Basic Biology to Clinical Application, Prof. Jamie Davies (Ed.), 2012; Chapter 8: 167-202. ISBN: 978-953-51-0387-5, InTech. Available from: https://cdn.intechopen. com/pdfs-wm/34637.pdf. Accessed December 21, 2018.

63. Drapeau C, Benson KF, James J, Jensen GS. Aloe macroclada from Madagascar triggers transient bone marrow stem cell mobilization. J Stem Cell Res Ther. 2015;05(06):287.

64. Shephard RJ. Adhesion molecules, catecholamines and leucocyte redistribution during and following exercise. Sports Med. 2003;33(4): 261-284.

65. Dimitrov S, Benedict C, Heutling D, Westermann J, Born J, Lange T. Cortisol and epinephrine control opposing circadian rhythms in T cell subsets. Blood. 2009;113(21):5134-5143.

66. Atanackovic D, Schnee B, Schuch G, et al. Acute psychological stress alerts the adaptive immune response: stress-induced mobilization of effector T cells. J Neuroimmunol. 2006;176(1-2):141-152.

67. Atanackovic D, Brunner-Weinzierl MC, Kröger H, Serke S, Deter HC. Acute psychological stress simultaneously alters hormone levels, recruitment of lymphocyte subsets, and production of reactive oxygen species. Immunol Invest. 2002;31(2):73-91.

68. Dimitrov S, Lange T, Nohroudi K, Born J. Number and function of circulating human antigen presenting cells regulated by sleep. Sleep. 2007;30(4):401-411.

69. Shah VO, Civin CI, Loken MR. Flow cytometric analysis of human bone marrow. IV. Differential quantitative expression of T-200 common leukocyte antigen during normal hemopoiesis. J Immunol. 1988; 140(6):1861-1867.

70. Chorváth B, Festin R, Sedlák J, Tötterman T, Nilsson K. Immunocytometric characteristics of a monoclonal antibody (Bra55) recognizing the leukocyte common antigen (LCA). Neoplasma. 1988;35(5):495-501.

71. Wu H, Yin Z, Wang L, Li F, Qiu Y. Honokiol improved chondrogenesis and suppressed inflammation in human umbilical cord derived mesenchymal stem cells via blocking nuclear factor- $\mathrm{\kappa B}$ pathway. BMC Cell Biol. 2017;18(1):29.

72. Ziegler BL, Valtieri M, Porada GA, et al. KDR receptor: a key marker defining hematopoietic stem cells. Science. 1999;285(5433):1553-1558.

73. de Boer HC, Hovens MM, van Oeveren-Rietdijk AM, et al. Human $\mathrm{CD} 34^{+} / \mathrm{KDR}+$ cells are generated from circulating CD34+ cells after immobilization on activated platelets. Arterioscler Thromb Vasc Biol. 2011;31(2):408-415.

74. Duda DG, Cohen KS, Scadden DT, Jain RK. A protocol for phenotypic detection and enumeration of circulating endothelial cells and circulating progenitor cells in human blood. Nat Protoc. 2007;2(4): $805-810$.

75. Bompais H, Chagraoui J, Canron X, et al. Human endothelial cells derived from circulating progenitors display specific functional properties compared with mature vessel wall endothelial cells. Blood. 2004;103(7):2577-2584.
76. Shintani S, Murohara T, Ikeda H, et al. Mobilization of endothelial progenitor cells in patients with acute myocardial infarction. Circulation. 2001;103(23):2776-2779.

77. Regueiro A, Cuadrado-Godia E, Bueno-Betí C, et al. Mobilization of endothelial progenitor cells in acute cardiovascular events in the PROCELL study: time-course after acute myocardial infarction and stroke. J Mol Cell Cardiol. 2015;80:146-155.

78. Werner N, Kosiol S, Schiegl T, et al. Circulating endothelial progenitor cells and cardiovascular outcomes. N Engl J Med. 2005;353(10): 999-1007.

79. Tomoda H, Aoki N. Bone marrow stimulation and left ventricular function in acute myocardial infarction. Clin Cardiol. 2003;26(10): 455-457.

80. Fadini GP, Boscaro E, de Kreutzenberg S, et al. Time course and mechanisms of circulating progenitor cell reduction in the natural history of type 2 diabetes. Diabetes Care. 2010;33(5):1097-1102.

81. Bozdag-Turan I, Turan RG, Turan $\mathrm{CH}$, et al. Relation between the frequency of $\mathrm{CD} 34^{+}$bone marrow derived circulating progenitor cells and the number of diseased coronary arteries in patients with myocardial ischemia and diabetes. Cardiovasc Diabetol. 2011;10(1):107.

82. Zenovich AG, Taylor DA. Atherosclerosis as a disease of failed endogenous repair. Front Biosci. 2008;13(13):3621-3636.

83. Fadini GP, Coracina A, Baesso I, et al. Peripheral blood CD34+KDR+ endothelial progenitor cells are determinants of subclinical atherosclerosis in a middle-aged general population. Stroke. 2006;37(9):2277-2282.

84. Lee ST, Chu K, Jung KH, et al. Reduced circulating angiogenic cells in Alzheimer disease. Neurology. 2009;72(21):1858-1863.

85. Kong XD, Zhang Y, Liu L, Sun N, Zhang MY, Zhang JN. Endothelial progenitor cells with Alzheimer's disease. Chin Med J (Engl). 2011; 124(6):901-906.

86. Grisar J, Aletaha D, Steiner CW, et al. Depletion of endothelial progenitor cells in the peripheral blood of patients with rheumatoid arthritis. Circulation. 2005;111(2):204-211.

87. Herbrig K, Haensel S, Oelschlaegel U, Pistrosch F, Foerster S, Passauer J. Endothelial dysfunction in patients with rheumatoid arthritis is associated with a reduced number and impaired function of endothelial progenitor cells. Ann Rheum Dis. 2006;65(2):157-163.

88. Diller GP, van Eijl S, Okonko DO, et al. Circulating endothelial progenitor cells in patients with Eisenmenger syndrome and idiopathic pulmonary arterial hypertension. Circulation. 2008;117(23):3020-3030.

89. Palange P, Testa U, Huertas A, et al. Circulating haemopoietic and endothelial progenitor cells are decreased in COPD. Eur Respir J. 2006;27(3):529-541.

90. Esposito K, Ciotola M, Maiorino MI, et al. Circulating CD34+ KDR+ endothelial progenitor cells correlate with erectile function and endothelial function in overweight men. J Sex Med. 2009;6(1):107-114.

91. Foresta C, Caretta N, Lana A, Cabrelle A, Palù G, Ferlin A. Circulating endothelial progenitor cells in subjects with erectile dysfunction. Int $J$ Impot Res. 2005;17(3):288-290.

92. Marchesi C, Belicchi M, Meregalli M, et al. Correlation of circulating CD133+ progenitor subclasses with a mild phenotype in Duchenne muscular dystrophy patients. PLoS One. 2008;3(5):e2218.

93. Kanellakis P, Slater NJ, Du XJ, Bobik A, Curtis DJ. Granulocyte colonystimulating factor and stem cell factor improve endogenous repair after myocardial infarction. Cardiovasc Res. 2006;70(1):117-125.

94. Luo Y, Zhao X, Zhou X, et al. Short-term intermittent administration of CXCR4 antagonist AMD3100 facilitates myocardial repair in experimental myocardial infarction. Acta Biochim Biophys Sin (Shanghai). 2013;45(7):561-569.

95. Wang LL, Chen D, Lee J, et al. Mobilization of endogenous bone marrow derived endothelial progenitor cells and therapeutic potential of parathyroid hormone after ischemic stroke in mice. PLoS One. 2014; 9(2):e87284.

96. Toupadakis CA, Granick JL, Sagy M, et al. Mobilization of endogenous stem cell populations enhances fracture healing in a murine femoral fracture model. Cytotherapy. 2013;15(9):1136-1147. 
97. Stratos I, Rotter R, Eipel C, Mittlmeier T, Vollmar B. Granulocytecolony stimulating factor enhances muscle proliferation and strength following skeletal muscle injury in rats. $J$ Appl Physiol. 2007;103(5):1857-1863.

98. Urdziková L, Likavčanová-Mašínová K, Vaněček V, et al. Flt3 ligand synergizes with granulocyte-colony-stimulating factor in bone marrow mobilization to improve functional outcome after spinal cord injury in the rat. Cytotherapy. 2011;13(9):1090-1104.

99. Nishimura Y, Ii M, Qin G, et al. CXCR4 antagonist AMD3100 accelerates impaired wound healing in diabetic mice. $J$ Invest Dermatol. 2012;132(3 Pt 1):711-720.

100. Elbana AM, Abdel-Salam S, Morad GM, Omran AA. Role of endogenous bone marrow stem cells mobilization in repair of damaged inner ear in rats. Int J Stem Cells. 2015;8(2):146-154.

101. Wang YB, Liu YF, Lu XT, et al. Rehmannia glutinosa extract activates endothelial progenitor cells in a rat model of myocardial infarction through a SDF-1 $\alpha /$ CXCR4 cascade. PLoS One. 2013;8(1):e54303.

102. Lee DE, Ayoub N, Agrawal DK. Mesenchymal stem cells and cutaneous wound healing: novel methods to increase cell delivery and therapeutic efficacy. Stem Cell Res Ther. 2016;7(1):37.
103. Lee S, Zhang QZ, Karabucak B, Le AD. DPSCs from Inflamed pulp modulate macrophage function via the TNF- $\alpha /$ IDO Axis. J Dent Res. 2016;95(11):1274-1281.

104. Sica A, Mantovani A. Macrophage plasticity and polarization: in vivo veritas. J Clin Invest. 2012;122(3):787-795.

105. Xu J, Wu W, Zhang L, et al. The role of microRNA-146a in the pathogenesis of the diabetic wound-healing impairment: correction with mesenchymal stem cell treatment. Diabetes. 2012;61(11):2906-2912.

106. Sykova E, Forostyak S. Stem cells in regenerative medicine. Laser Ther. 2013;22(2):87-92.

107. Kornicka K, Kocherova I, Marycz K. The effects of chosen plant extracts and compounds on mesenchymal stem cells-a bridge between molecular nutrition and regenerative medicine-concise review. Phytother Res. 2017;31(7):947-958.

108. Spinetti G, Mangialardi G, Specchia C, Madeddu P. Enhancing stem cell mobility: new hope for treatment of cardiovascular complications in patients with diabetes? Diabetes. 2015;64(8):2704-2707.

109. Orlic D, Kajstura J, Chimenti S, et al. Mobilized bone marrow cells repair the infarcted heart, improving function and survival. Proc Natl Acad Sci U S A. 2001;98(18):10344-10349.
Clinical Interventions in Aging

\section{Publish your work in this journal}

Clinical Interventions in Aging is an international, peer-reviewed journal focusing on evidence-based reports on the value or lack thereof of treatments intended to prevent or delay the onset of maladaptive correlates of aging in human beings. This journal is indexed on PubMed Central, MedLine,

\section{Dovepress}

CAS, Scopus and the Elsevier Bibliographic databases. The manuscript management system is completely online and includes a very quick and fair peer-review system, which is all easy to use. Visit http://www.dovepress. com/testimonials.php to read real quotes from published authors. 